ISSN: 1858-4837; E-ISSN: 2598-019X

Volume 16, Nomor 2 (2021),

https://jurnal.uns.ac.id/region

DOI: $10.20961 /$ region.v16i2.25468

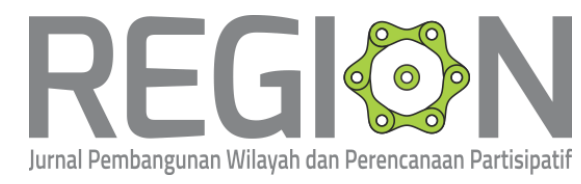

\title{
Studi kesesuaian lahan pertanian sawah organik (Studi kasus: Desa Gempol, Kabupaten Klaten)
}

\author{
Land suitability study of organic farming (Case study : Gempol Village, Klaten \\ Regency)
}

\author{
R Andrea ${ }^{1}$, I Aliyah ${ }^{1}$, dan G Yudana ${ }^{1}$ \\ ${ }^{1}$ Program Studi Perencanaan Wilayah dan Kota, Fakultas Teknik, Universitas Sebelas \\ Maret
}

Corresponding author's email: andre27roofid@gmail.com

\begin{abstract}
Abstrak. Kabupaten Klaten memiliki visi untuk menjadi lumbung padi dan menjadi kawasan agropolitan terbesar di provinsi Jawa Tengah. Pertanian di Kabupaten Klaten masih menggunakan teknik pertanian anorganik atau masih menggunakan bahanbahan kimia dalam pelaksanannya. Penggunaan bahan-bahan kimia yang berlebihan akhirnya menyebabkan kerusakan kondisi lingkungan dan kesehatan manusia. Para petani yang sadar terhadap bahaya tersebut akhirnya melakukan teknik bercocok tanam yang lebih ramah lingkungan atau disebut pertanian organik. Pertanian sawah organik yang menonjol di Kabupaten Klaten terdapat di Desa Gempol Kecamatan Karanganom. Penelitian ini bertujuan untuk mengetahui kesesuaian lahan Desa Gempol terhadap pertanian sawah organik. Metode yang digunakan pada penelitian ini yakni menggunakan analisis skoring untuk mengetahui kesesuaian lahan Desa Gempol terhadap pertanian organik. Berdasarkan hasil analisis skoring kemampuan lahan, maka diketahui bahwa Desa Gempol yang masuk kedalam kelas lahan III, dimana kelas lahan III diperuntukan sebagai lahan pertanian. Selain itu ditinjau dari analisis skoring jaringan irigasi di Desa Gempol sudah sesuai hanya terdapat beberapa zona yang tidak sesuai karena tata letak tanam yang jauh dari sumber air. Namun jika ditinjau dari hasil analisis skoring kemampuan lahan dan jaringan irigasi maka diketahui bahwa Desa Gempol sudah sesuai diperuntukan sebagai lahan pertanian organik.
\end{abstract}

Kata Kunci: Kesesuaian; Lahan; Organik; Pertanian

Received: November 21, 2018; Accepted: Januari 15, 2019; Available online: July 15, 2021

Copyright $\odot$ 2021, REGION: Jurnal Pembangunan Wilayah dan Perencanaan Partisipatif 


\begin{abstract}
Klaten Regency has a vision to become a rice barn and become the largest acropolitan area in Central Java. Agriculture in Klaten Regency uses inorganic farming techniques or chemicals in its implementation. The use of excessive chemicals ultimately damages the environment and human health. Farmers who are aware of these risks eventually do organic farming that are more environmentally friendly. Prominent organic farming in Klaten Regency is in Gempol Village, Karanganom District. This study aims to determine the suitability of Gempol Village land for organic farming. The method of this research used scoring analysis to determine the suitability of Gempol Village land for organic farming. Based on the results of land capability scoring analysis, Gempol Village land is classified as class III designated as agricultural land. Besides that, in terms of the irrigation network scoring analysis in Gempol Village, the majority of the zones are suitable. Some zones are not suitable due to the planting layout which is far from water sources. Viewed from the results of the land capability and irrigation network scoring analysis, it is known that Gempol Village is suitable for organic farming.
\end{abstract}

Keywords: Suitability; Land; Organic; Farming

\title{
1. Pendahuluan
}

Kabupaten Klaten merupakan kabupaten di Jawa Tengah yang memiliki luas wilayah yaitu $65.556 \mathrm{Ha}$, dengan luas lahan sebagai peruntukan lahan pertanian adalah $33.374 \mathrm{Ha}$ [1]. Penggunaan lahan pertanian yang cukup luas membuat pemerintah Kabupaten Klaten memiliki visi yang tertuang di dalam RTRW yaitu menjadikan Kabupaten Klaten sebagai salah satu lumbung padi terbesar di Jawa Tengah [2]. Pertanian di Kabupaten Klaten masih menggunakan teknik pertanian anorganik atau masih menggunakan bahan-bahan kimia dalam pelaksanaannya. Penggunaan bahan-bahan kimia yang berlebihan akhirnya menyebabkan kerusakan kondisi lingkungan dan kesehatan manusia. Para petani yang sadar terhadap bahaya tersebut akhirnya melakukan teknik bercocok tanam yang lebih ramah lingkuangan atau disebut pertanian organik.

Pertanian sawah organik yang berada di Kabupaten Klaten masih mempunyai masalah yaitu tidak meratanya pelaksanaan pertanian sawah organik sehingga masih banyak lahan pertanian sawah organik yang berbatasan langsung pertanian sawah anorganik. Pertanian sawah organik yang menonjol di Kabupaten Klaten terdapat di Desa Gempol Kecamatan Karanganom. Pertanian sawah organik di Desa Gempol sudah bersertifikasi yang diberikan oleh Lembaga Sertifikasi Organik Seloliman (LeSOS). Pertanian sawah organik di Desa Gempol dimulai dari tahun 2010 dengan hanya beberapa petak sawah milik petani. Berkembanganya pertanian sawah organik di Desa Gempol membuat lahan pertanian sawah organik di Desa Gempol mencapai 5,47 Ha dan masih berkembang.

Kesesuaian lahan adalah kecocokan persyaratan tumbuh tanaman sesuai kelas karakteristik lahan, yang diperoleh dari skor kemampuan lahan [3]. Berdasarkan Permen PU No.20 Tahun 2007, kemampuan lahan dapat ditinjau dari SKL Morfologi, SKL Kemudahan Dikerjakan, SKL Kestabilan Lereng, SKL Kestabilan Pondasi, SKL Ketersedian Air, SKL Drainase, SKL Terhadap 
Erosi, SKL Pembuangan Limbah, dan SKL Bencana Alam [4]. Dasar Standar Pertanian Organik Indonesia yang dibuat oleh Serikat Jaringan Kerja Pertanian Organik Indonesia, mengatakan bahwa prinsip ekologis dalam pengelolaan pertanian organik adalah mendasarkan diri pada keadaan sesuai dengan iklim dan tradisi setempat, serta harus memiliki saluran irigasi yang memiliki filter serta lahan yang bebas dari erosi. Menurut Peraturan Pemerintah Nomor 20 Tahun 2006 tentang Irigasi, jaringan irigasi meliputi prasarana irigasi, air irigasi, manajemen irigasi, kelembagaan pengelolaan irigasi, dan sumber daya manusia [5].

Tingginya perkembangan pertanian padi organik di Desa Gempol, Kabupaten Klaten ini, mendorong penulis untuk mengkaji kesesuaian lahan untuk pertanian organik yang berada di Desa Gempol Kabupaten Klaten.

\section{Metode}

Penelitian ini menggunakan pendekatan deduktif dengan jenis penelitian kuantitatif. Proses pengumpulan data menggunakan teknik survey primer, yaitu melakukan observasi terhadap penggunaan lahan pertanian sawah organik di Desa Gempol, Kabupaten Klaten dan menggunakan kuesioner terhadap seluruh petani sawah organik Desa Gempol. Berikut merupakan tolak ukur variabel pertanian yang dapat dilihat pada Tabel 1.

Tabel 1. Tolak ukur variabel pertanian.

\begin{tabular}{|c|c|c|c|}
\hline Variabel & Sub Variabel & Skor & Tolak Ukur \\
\hline \multirow[t]{11}{*}{$\begin{array}{l}\text { Kemampuan } \\
\text { Lahan }\end{array}$} & SKL Morfologi & 1 & $\begin{array}{c}\text { Lahan memiliki kemiringan }>40 \% \text { dengan morfologi } \\
\text { pegunungan dan perbukitan terjal }\end{array}$ \\
\hline & & 2 & $\begin{array}{l}\text { Lahan memiliki kemiringan } 15->40 \% \text { dengan morfologi } \\
\text { pegunungan, perbukitan terjal dan perbukitan sangat terjal }\end{array}$ \\
\hline & & 3 & $\begin{array}{l}\text { Lahan memiliki kemiringan } 5-40 \% \text { dengan morfologi } \\
\text { perbukitan sedang, pegunungan dan perbukitan terjal }\end{array}$ \\
\hline & & 4 & $\begin{array}{l}\text { Lahan memiliki kemiringan } 3-15 \% \text { dengan morfologi landai } \\
\text { dan perbukitan sedang }\end{array}$ \\
\hline & & 5 & $\begin{array}{l}\text { Lahan memiliki kemiringan } 0-5 \% \text { dengan morfologi dataran } \\
\text { dan landai }\end{array}$ \\
\hline & $\begin{array}{l}\text { SKL Kemudahan } \\
\text { Dikerjakan }\end{array}$ & 2 & $\begin{array}{l}\text { Lahan memiliki ketinggian } 1500-2500 \text { meter, dengan } \\
\text { kemiringan lahan }>40 \% \text { dan jenis tanah podsol merah kuning }\end{array}$ \\
\hline & & 3 & $\begin{array}{l}\text { Lahan memiliki ketinggian 500-1500 meter dengan } \\
\text { kemiringan 5-40\% dengan jenis tanah brown forest, dan } \\
\text { mediteran }\end{array}$ \\
\hline & & 4 & $\begin{array}{l}\text { Lahan memiliki ketinggian }<500 \text { meter dengan kemiringan } 3 \text { - } \\
\qquad 5 \% \text { dan jenis tanah latosol }\end{array}$ \\
\hline & & 5 & $\begin{array}{l}\text { Lahan memiliki ketinggian }<500 \text { meter dengan kemiringan } 0 \text { - } \\
\qquad 2 \% \text { dan memiliki jenis tanah alluvial }\end{array}$ \\
\hline & $\begin{array}{l}\mathrm{SKL} \\
\text { Ketersediaan Air }\end{array}$ & 2 & $\begin{array}{l}\text { Lahan dilalui sungai dengan debit air kecil dengan tingkat } \\
\text { curah hujan 2500-3000 mm pertahun dan guna lahan tidak } \\
\text { terbangun }\end{array}$ \\
\hline & & 3 & $\begin{array}{l}\text { Lahan dilalui sungai dengan debit air yang baik tetapi tidak } \\
\text { menjangakau seluruh lahan pertanian, dengan tingkat curah } \\
\text { hujan } 2500-3500 \mathrm{~mm} \text { pertahun dan guna lahan tidak } \\
\text { terbangun }\end{array}$ \\
\hline
\end{tabular}




\begin{tabular}{|c|c|c|c|}
\hline \multirow[t]{17}{*}{ Variabel } & Sub Variabel & Skor & Tolak Ukur \\
\hline & & 5 & $\begin{array}{l}\text { Lahan dilalui sungai dengan debit air yang baik dan dapat } \\
\text { menjangkau seluruh lahan pertanian, dengan tingkat curah } \\
\text { hujan 3000-4000 mm pertahun dan guna lahan terbangun } \\
\text { Lahan dilalui sungai dengan debit air yang baik dan dapat } \\
\text { menjangkau seluruh lahan pertanian, dengan tingkat curah } \\
\text { hujan 3500-4500 mm pertahun dan guna lahan terbangun }\end{array}$ \\
\hline & $\begin{array}{l}\text { SKL Kestabilan } \\
\text { Lereng }\end{array}$ & 1 & $\begin{array}{l}\text { Lahan memiliki ketinggian 1500-2500 meter, dengan } \\
\text { ketinggian }>40 \% \text { dan morfologi pegunungan dan perbukitan } \\
\text { sangat terjal }\end{array}$ \\
\hline & & 2 & $\begin{array}{l}\text { Lahan memiliki ketinggian } 1500-2500 \text { meter, dengan } \\
\text { kemiringan } 15->40 \% \text { dengan morfologi pegunungan, } \\
\text { perbukitan terjal dan perbukitan sangat terjal }\end{array}$ \\
\hline & & 3 & $\begin{array}{l}\text { Lahan memiliki ketinggian } 500-1500 \text { meter, dengan } \\
\text { kemiringan } 5-40 \% \text { dan memiliki morfologi perbukitan sedang, } \\
\text { pegunungan, perbukitan sedang dan perbukitan terjal }\end{array}$ \\
\hline & & 4 & $\begin{array}{l}\text { Lahan mamiliki ketinggain }<500-1500 \text { meter, dengan } \\
\text { kemiringan 3-15\% dan morfologi landai serta perbukitan } \\
\text { sedang }\end{array}$ \\
\hline & & 5 & $\begin{array}{l}\text { Lahan memiliki ketinggian }<500-1500 \text { meter, dengan } \\
\text { kemiringan } 0-5 \% \text { dengan morfologi dataran dan landai }\end{array}$ \\
\hline & $\begin{array}{l}\text { SKL Terhadap } \\
\text { Erosi }\end{array}$ & 2 & $\begin{array}{l}\text { Lahan memiliki kemiringan } 40 \%>\text { dengan morfologi } \\
\text { perbukitan sedang }\end{array}$ \\
\hline & & 3 & $\begin{array}{l}\text { Lahan memiliki kemiringan } 15-40 \% \text { dengan morfologi } \\
\text { perbukitan sangat terjal }\end{array}$ \\
\hline & & 4 & $\begin{array}{l}\text { Lahan memiliki kemiringan } 5-15 \% \text { dengan morfologi } \\
\text { perbukitan terjal }\end{array}$ \\
\hline & & 5 & $\begin{array}{l}\text { Lahan memiliki kemiringan } 0-5 \% \text { dengan morfologi } \\
\text { perbukitan sedang }\end{array}$ \\
\hline & SKL Drainase & 1 & $\begin{array}{l}\text { Lahan memiliki ketinggian } 1500-2500 \text { meter dengan } \\
\text { kemiringan }>40 \% \text { dengan tingkat curah hujan } 4000-4500 \mathrm{~mm} \\
\text { pertahun }\end{array}$ \\
\hline & & 2 & $\begin{array}{l}\text { Lahan memiliki ketinggian } 500-1500 \mathrm{~mm} \text { pertahun dengan } \\
\text { kemiringan 5-40\% dengan tingkat curah hujan 3000-4000 mm } \\
\text { pertahun }\end{array}$ \\
\hline & & 3 & $\begin{array}{l}\text { Lahan memiliki ketinggian }<500 \text { meter dengan kemiringan 0- } \\
5 \% \text { dan tingkat curah hujan } 2500-300 \text { o mm pertahun }\end{array}$ \\
\hline & $\begin{array}{l}\text { SKL Bencana } \\
\text { Alam }\end{array}$ & 3 & $\begin{array}{l}\text { Lahan memiliki resiko pergerakan tanah rendah dan sangat } \\
\text { rendah dengan zona rawan gempa rendah yaitu } 0,1-0,2 \mathrm{~g}\end{array}$ \\
\hline & & 4 & $\begin{array}{l}\text { Lahan memiliki resiko pergerakan tanah menengah dengan } \\
\text { zona rawan gempa yaitu } 0,3-0,4 \mathrm{~g}\end{array}$ \\
\hline & & 5 & $\begin{array}{l}\text { Lahan memiliki tingkat resiko pergerakan tanah tinggi dengan } \\
\text { zona rawan gempa tinggi yaitu }>0,4 \mathrm{~g}\end{array}$ \\
\hline \multirow[t]{3}{*}{$\begin{array}{l}\text { Prasarana } \\
\text { Irigasi }\end{array}$} & $\begin{array}{l}\text { Kelengkapan } \\
\text { Jaringan Irigasi }\end{array}$ & 1 & $\begin{array}{c}\text { Sumber air berasal dari saluran irigasi/sumber lain dan letak } \\
\text { petak sawah organik lebih jauh dibandingkan petak sawah } \\
\text { anorganik }\end{array}$ \\
\hline & & 2 & $\begin{array}{c}\text { Sumber air berasal dari saluran irigasi dan letak petak sawah } \\
\text { organik lebih dekat dengan sumber air dibandingkan } \\
\text { anorganik }\end{array}$ \\
\hline & & 3 & $\begin{array}{l}\text { Air berasal dari sumber air tanah langsung tanpa media } \\
\text { penyalur (saluran irigasi atau pipa irigasi) }\end{array}$ \\
\hline
\end{tabular}


Kemampuan lahan diketahui melalui hasil dari pembobotan setiap SKL, lalu kemudian dilakukan skoring untuk mengetahui kemampuan lahan. Perhitungan tersebut bisa dilakukan dengan mengkalikan hasil akhir SKL dengan bobot masing-masing SKL.

\section{Hasil penelitian dan pembahasan}

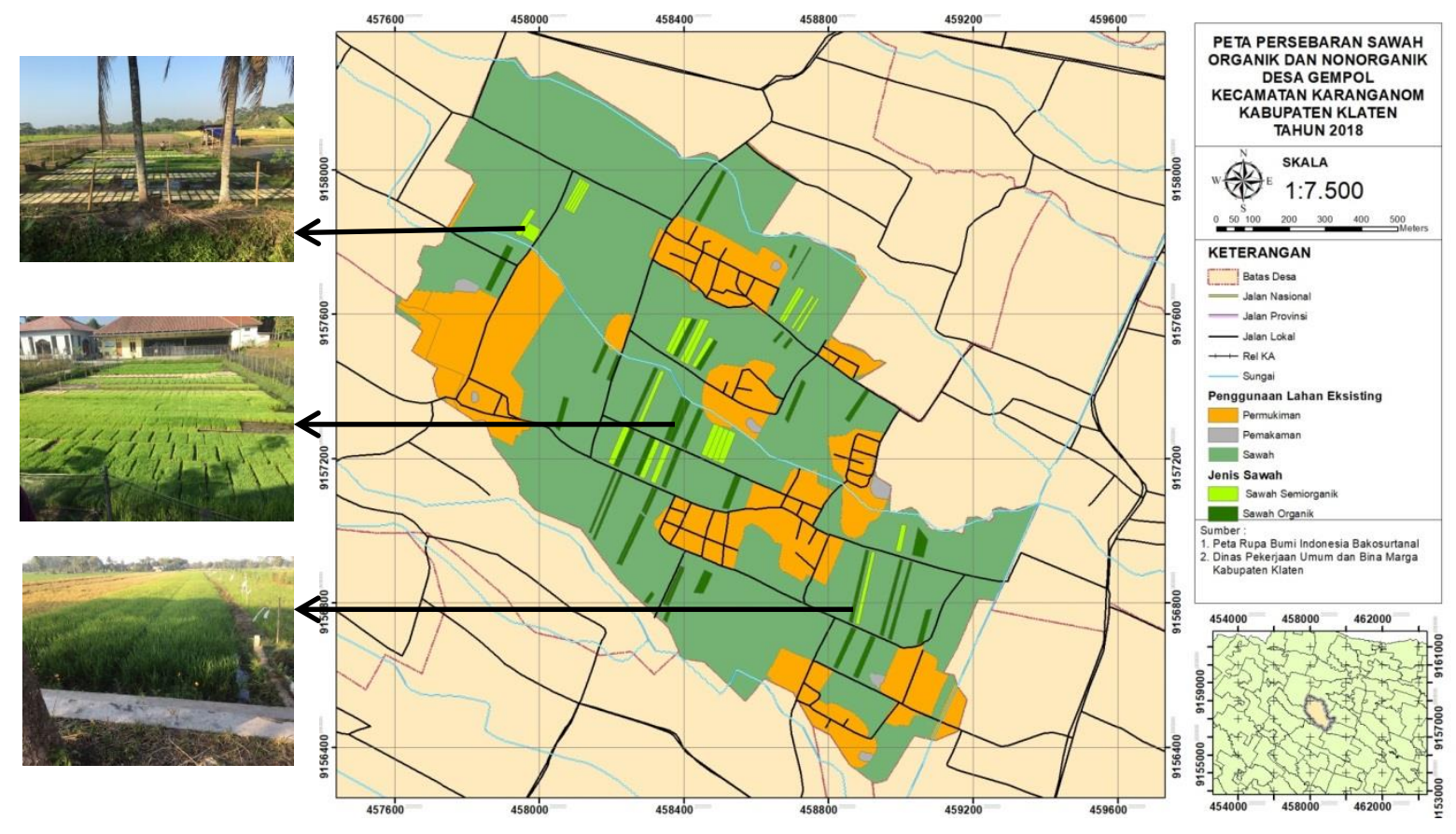

Gambar 1. Peta persebaran sawah organik Desa Gempol.

\subsection{Pemetaan lahan pertanian sawah organik}

Penggunaan lahan di Desa Gempol terdiri dari permukiman dan lahan pertanian (lihat Gambar 1). Jika ditinjau dari peta guna lahan Desa Gempol maka dapat diketahui bahwa seluruh permukiman tersebar di seluruh Desa Gempol dengan berkelompok serta mengelilingi fasilitas-fasilitas desa, seperti masjid, sekolah, dan pamsimas warga. Menurut Daldjoeni [6], pola tata guna lahan di desa terdiri dari linear, yaitu pola permukiman mengikuti jalan, alur sungai, atau memanjang mengikuti garis pantai. Berdasarkan teori tersebut, maka dapat diketahui guna lahan Desa Gempol termasuk pada pola desa yang mengelilingi fasilitas tertentu.

Berdasarkan pola guna lahan pertanian sawah organik di Desa Gempol maka dapat diketahui bahwa petak sawah organik tersebar di seluruh Desa Gempol. Menurut paul H. Landis dalam Bintarto [7], pola guna lahan di desa dibagi menjadi empat jenis yaitu the farm type dimana penduduk tinggal dalam satu kelompok dan dikelilingi lahan pertanian, the nebulous type dimana penduduk tinggal dan dikelilingi lahan pertanian akan tetapi terdapat beberapa penduduk yang tinggal di luar desa karena jumlah penduduk meningkat, the arranged isolated farm type adalah penduduk desa bermukim di sepanjang jalan utama selanjutnya pure isolated type adalah desa yang penduduknya dan lahan pertaniannya tersebar. Berdasarkan 
teori tersebut, maka diketahui bahwa pola guna lahan pertanian di Desa Gempol termasuk ke dalam kategori farm village type karena lahan pertanian di Desa Gempol mengelilingi permukiman di Desa Gempol dan seluruh permukiman tersebut tidak berada di sepanjang jalan utama desa melainkan mengelompok dan menyebar di seluruh Desa Gempol.

Seluruh petak sawah organik di Desa Gempol sudah mengalami masa konversi selama 2 tahun, tetapi letak petak sawah organik di Desa Gempol tidak dikelompokkan dan masih terpencar di setiap zona di Desa Gempol, hal ini menyebabkan dalam satu zona terdapat petak sawah organik dan anorganik. Hal tersebut dapat menyebabkan petak sawah organik dapat tercemar bahan-bahan kimia yang berasal dari pertanian anorganik melalui air irigasi. Untuk mengatasi hal tersebut, maka dilakukan pencegahan dengan membuat kolam filter yang dilengkapi dengan tanaman eceng gondok sebagai penyaring bahan kimia. Bardasarkan hasil observasi yang telah dilakukan, maka diketahui bahwa setiap petak sawah organik di Desa Gempol sudah dilengkapi dengan kolam filter yang ditanami dengan eceng gondok. Menurut SNI Sistem Pertanian Organik [8], mengatakan bahwa lahan yang akan digunakan sebagai lahan pertanian organik harus terlebih dahulu mengalami masa konversi selama dua tahun dan lahan pertanian sawah organik harus menggunakan pupuk alami dengan saluran irigasi yang memiliki filter yang dilengkapi eceng gondok untuk mencegah terjadinya kontaminasi bahan kimia. Berdasarkan teori di atas, maka dapat diketahui bahwa seluruh petak sawah organik di Desa Gempol sudah sesuai dengan ketentuan, seperti masa konversi lahan selama dua tahun dan terdapat kolam filter di setiap petak sawah organik.

Berdasarkan RTRW Kabupaten Klaten disebutkan bahwa Kabupaten Klaten memiliki visi untuk menjadi lumbung padi terbesar di Jawa Tengah [2]. Selain itu seiring berjalannya waktu, manusia menyadari bahaya penggunaan bahan kimia bagi lingkuangan maupun kesehatan manusia. Maka dari itu, dikembangkan pertanian sawah organik sebagai solusi atas permasalahan tersebut. Salah satu lahan pertanian sawah organik yang paling terbesar di Kabupaten Klaten yaitu Desa Gempol, Kecamatan Karanganom. Desa Gempol, Kecamatan Karanganom, Kabupaten Klaten memiliki keistimewaan di bidang pertanian organik dimana desa tersebut sudah memiliki kelembagaan pertanian organik, yakni kelompok tani "Dewi Ratih" serta memiliki standar operasional khusus pertanian organik. Selain itu, dari standar pertanian organik "Dewi Ratih" juga diatur mengenai segala bentuk pelanggaran terhadap implementasi pertanian organik berserta dengan sanksinya [9]. Dari hal tersebut, diketahui bahwa Desa Gempol memiliki keistimewaan tersendiri sebagai desa percontohan untuk pertanian organik.

\subsection{Identifikasi satuan kemampuan lahan dan jaringan irigasi pertanian organik}

3.2.1 SKL morfologi. Berdasarkan hasil skoring diketahui bahwa seluruh zona pertanian organik di Desa Gempol memperoleh skor satuan kemampuan lahan morfologi dengan nilai 4 dapat dilihat pada Tabel 2. Berikut peta SKL morfologi Desa Gempol (lihat Gambar 2). 


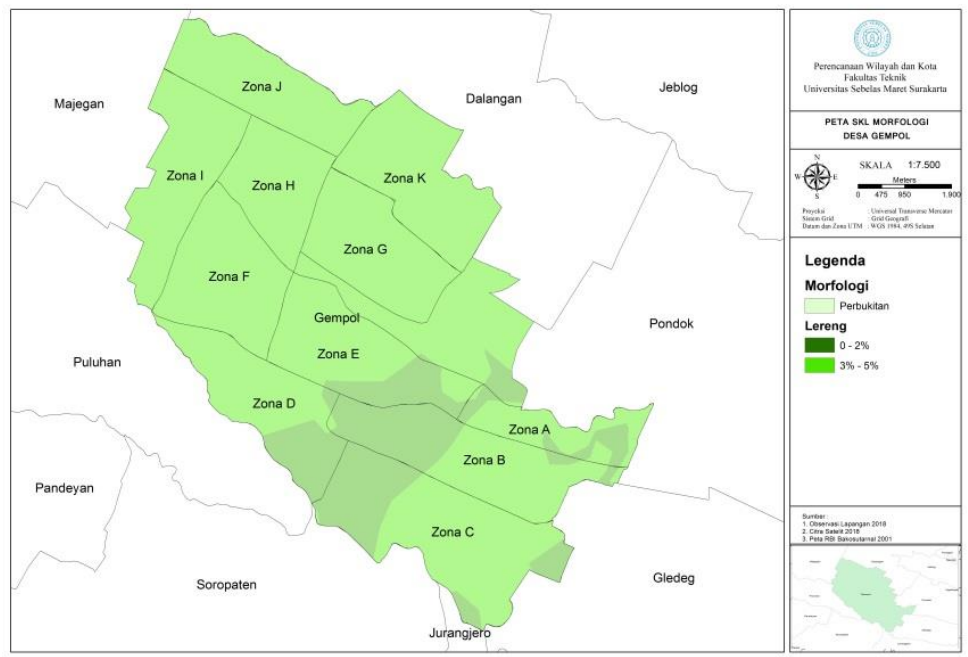

Tabel 2. Skoring SKL morfologi Desa Gempol.

\begin{tabular}{cc}
\hline ZONA & SKOR \\
\hline A & 4 \\
B & 4 \\
C & 4 \\
D & 4 \\
E & 4 \\
F & 4 \\
G & 4 \\
H & 4 \\
I & 4 \\
J & 4 \\
K & 4 \\
\hline
\end{tabular}

Gambar 2. Peta SKL morfologi Desa Gempol.

3.2.2 SKL kemudahan dikerjakan. Berdasarkan hasil skoring diketahui bahwa seluruh zona pertanian organik di Desa Gempol memperoleh skor satuan kemampuan lahan terhadap kemudahan dikerjakan dengan nilai 4 (lihat Tabel 3). Berikut merupakan peta SKL kemudahan dikerjakan Desa Gempol yang tertera pada Gambar 3.

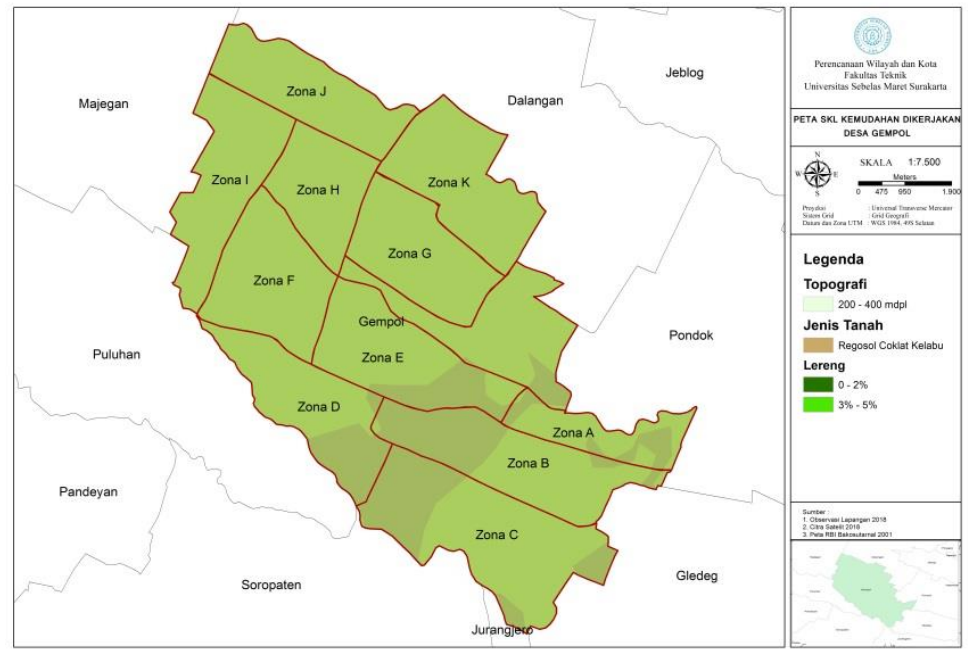

Tabel 3. Skoring SKL kemudahan dikerjakan Desa Gempol.

\begin{tabular}{cc}
\hline ZONA & SKOR \\
\hline A & 4 \\
B & 4 \\
C & 4 \\
D & 4 \\
E & 4 \\
F & 4 \\
G & 4 \\
H & 4 \\
I & 4 \\
J & 4 \\
K & 4 \\
\hline
\end{tabular}

Gambar 3. Peta SKL kemudahan dikerjakan Desa Gempol.

3.2.3 SKL kestabilan lereng. Berdasarkan hasil skoring diketahui bahwa seluruh zona pertanian organik di Desa Gempol memperoleh skor satuan kemampuan lahan terhadap kestabilan lereng dengan nilai 4 (lihat Tabel 4). Berikut merupakan peta SKL kestabilan lereng Desa Gempol yang dapat dilihat pada Gambar 4. 


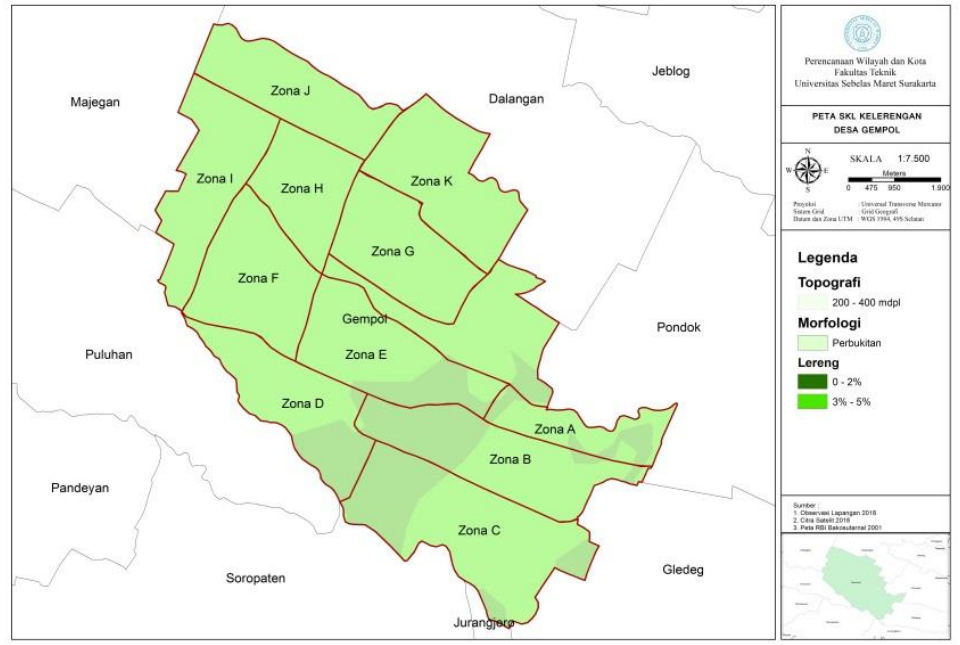

Tabel 4. Skoring SKL kestabilan lereng Desa Gempol.

\begin{tabular}{cc}
\hline ZONA & SKOR \\
\hline A & 4 \\
B & 4 \\
C & 4 \\
D & 4 \\
E & 4 \\
F & 4 \\
G & 4 \\
H & 4 \\
I & 4 \\
J & 4 \\
K & 4 \\
\hline
\end{tabular}

Gambar 4. Peta SKL kestabilan lereng Desa Gempol.

3.2.4 SKL ketersediaan air. Berdasarkan hasil skoring diketahui bahwa seluruh zona pertanian organik di Desa Gempol memperoleh skor satuan kemampuan lahan terhadap ketersediaan air dengan nilai 4 kecuali pada Zona J memperoleh skor 3 (lihat Tabel 5). Berikut merupakan peta SKL ketersediaan air Desa Gempol yang tertera pada Gambar 5.

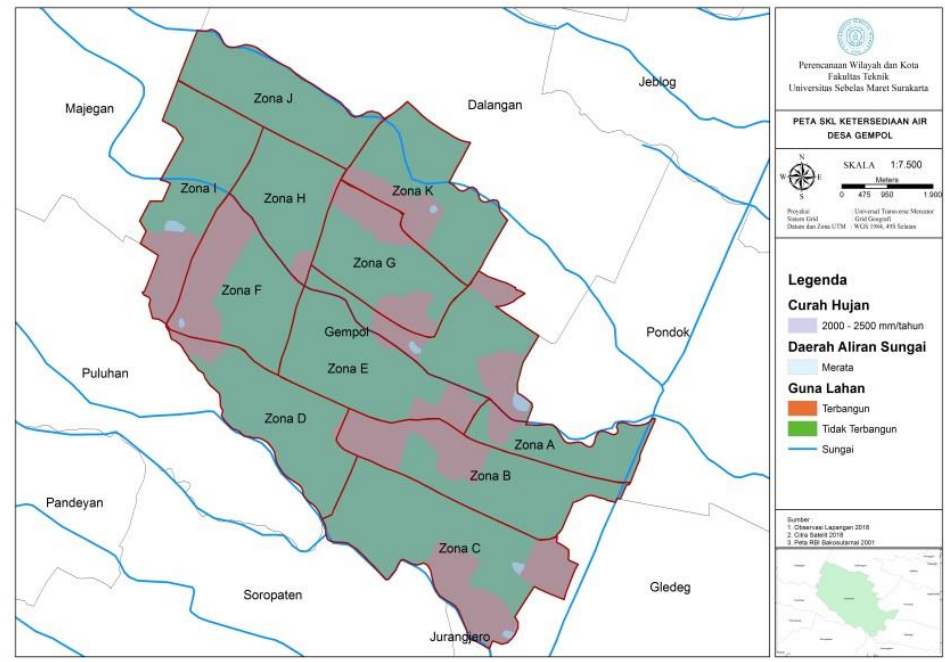

Tabel 5. Skoring SKL ketersediaan air Desa Gempol.

\begin{tabular}{cc}
\hline ZONA & SKOR \\
\hline A & 4 \\
B & 4 \\
C & 4 \\
D & 4 \\
E & 4 \\
F & 4 \\
G & 4 \\
H & 4 \\
I & 4 \\
J & 3 \\
K & 4 \\
\hline
\end{tabular}

Gambar 5. Peta SKL ketersediaan air Desa Gempol.

3.2.5 SKL terhadap erosi. Berdasarkan hasil skoring diketahui bahwa seluruh zona pertanian organik di Desa Gempol memperoleh skor satuan kemampuan lahan terhadap erosi dengan nilai 5 (lihat Tabel 6). Berikut merupakan peta SKL terhadap erosi di Desa Gempol yang dapat dilihat pada Gambar 6. 


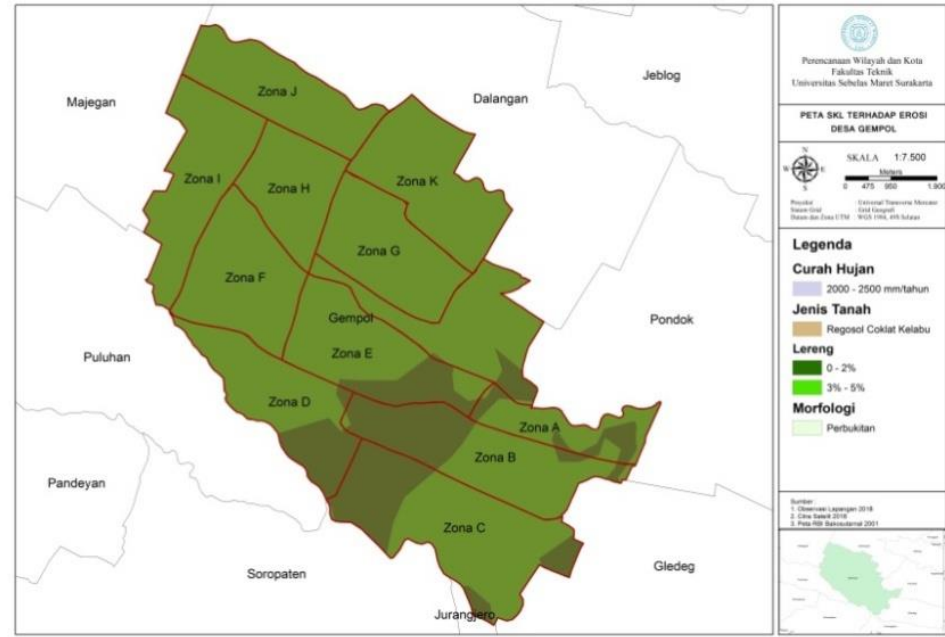

Tabel 6. Skoring SKL terhadap erosi Desa Gempol.

\begin{tabular}{cc}
\hline ZONA & SKOR \\
\hline A & 5 \\
B & 5 \\
C & 5 \\
D & 5 \\
E & 5 \\
F & 5 \\
G & 5 \\
H & 5 \\
I & 5 \\
J & 5 \\
K & 5 \\
\hline
\end{tabular}

Gambar 6. Peta SKL terhadap erosi Desa Gempol.

3.2.6 SKL drainase. Berdasarkan hasil skoring diketahui bahwa seluruh zona pertanian organik di Desa Gempol memperoleh skor satuan kemampuan lahan terhadap drainase, yakni 3 untuk Zona A hingga Zona E, sedangkan Zona F hingga Zona K memperoleh skor 2 (lihat Tabel 7). Berikut merupakan peta SKL drainase Desa Gempol yang dapat dilihat pada Gambar 7.

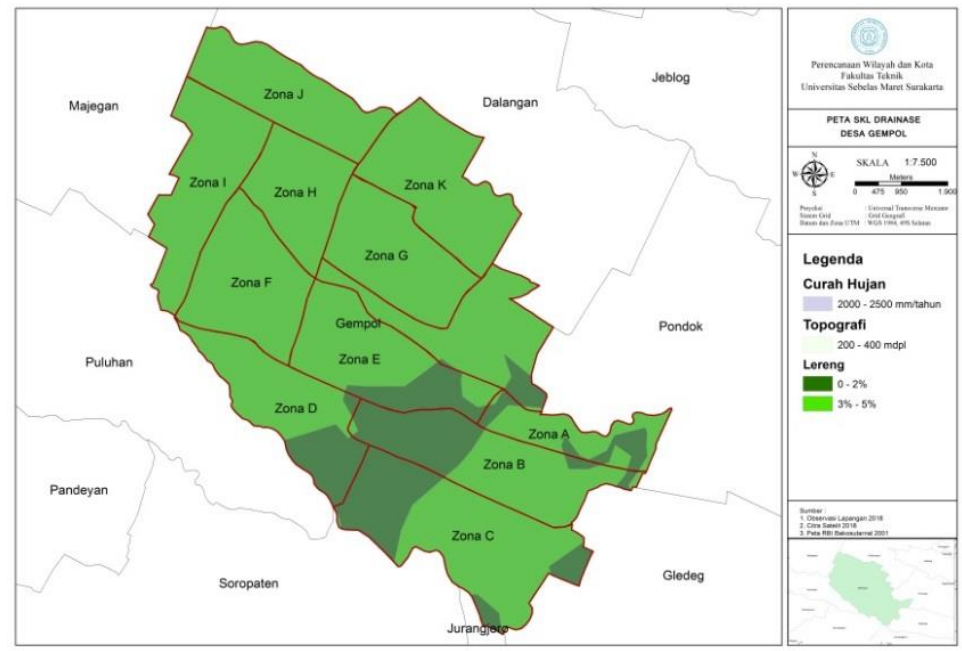

Tabel 7. Skoring SKL drainase Desa Gempol.

\begin{tabular}{cc}
\hline ZONA & SKOR \\
\hline A & 3 \\
B & 3 \\
C & 3 \\
D & 3 \\
E & 3 \\
F & 2 \\
G & 2 \\
H & 2 \\
I & 2 \\
J & 2 \\
K & 2 \\
\hline
\end{tabular}

Gambar 7. Peta SKL drainase Desa Gempol.

3.2.7 SKL bencana alam. Berdasarkan hasil skoring diketahui bahwa seluruh zona pertanian organik di Desa Gempol memperoleh skor satuan kemampuan lahan terhadap bencana alam, yakni 3 untuk Zona A hingga Zona E, sedangkan Zona F hingga Zona K memperoleh skor 4 (lihat Tabel 8). Berikut merupakan peta SKL bencana alam yang dapat dilihat pada Gambar 8. 


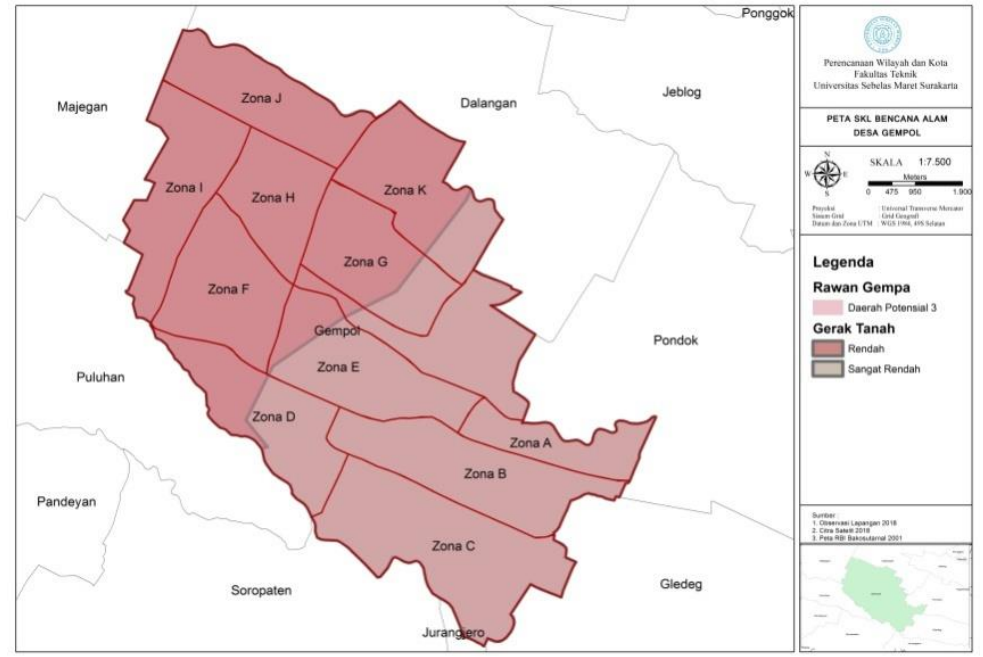

Tabel 8. Skoring SKL drainase Desa

\begin{tabular}{cc}
\multicolumn{2}{c}{ Gempol. } \\
\hline ZONA & SKOR \\
\hline A & 3 \\
B & 3 \\
C & 3 \\
D & 3 \\
E & 3 \\
F & 4 \\
G & 4 \\
H & 4 \\
I & 4 \\
J & 4 \\
K & 4 \\
\hline
\end{tabular}

Gambar 8. Peta SKL bencana alam Desa Gempol.

3.2.8 Jaringan irigasi. Berdasarkan hasil analisis yang dapat dilihat pada Tabel 9, maka diketahui bahwa Zona A, B, C, D dan J memiliki jarak yang paling jauh dari sumber air, sedangkan pada Zona $\mathrm{E}, \mathrm{F}, \mathrm{I}$, dan $\mathrm{K}$ adalah zona yang berbatasan langsung dengan sumber air. Pada Zona $\mathrm{G}$ dan $\mathrm{H}$ adalah zona yang sangat sesuai untuk pertanian organik karena terdapat sumber air pada Zona G dan Zona H. Pada setiap petak sawah pertanian sawah organik sudah terdapat kolam filter dengan menggunakan tanaman enceng gondok serta border tanaman untuk menghindari pencemaran bahan-bahan kimia baik dari udara maupun air. Menurut Sopian [10], penyediaan jaringan irigasi dilakukan dalam rangka untuk meningkatkan produksi pertanian, untuk itu diperlukan upaya demi kelestarian sarana irigasi. Berdasarkan teori tersebut, diketahui bahwa jaringan irigasi di Desa Gempol sesuai dengan teori tersebut karena jaringan irigasi telah dilengkapi oleh kolam filter berupa tanaman enceng gondong yang bertujuan untuk mengurangi pencemaran bahan kimia melalui saluran air irigasi serta untuk kelestarian lingkungan.

Berdasarkan SOP pertanian organik Desa Gempol, diketahui bahwa saluran irigasi untuk pertanian sawah organik harus terbebas dari bahan-bahan kimia. Penggunaan bahan kimia pada pertanian sawah anorganik tentunya dapat membuat air ikut tercemar. Oleh karena itu, pada SOP pertanian organik Desa Gempol dikatakan bahwa setiap petak sawah pertanian organik harus dilengkapi dengan kolam filter yang dilengkapi dengan eceng gondok. Berdasarkan teori SOP di atas, maka dapat dikatakan bahwa tata letak tanaman berpengaruh terhadap kualitas air, semakin jauh letak petak sawah organik dari sumber air maka kemungkinan tercemarnya air semakin tinggi. Pada SOP pertanian organik dikatakan bahwa sumber air untuk pertanian sawah organik berasal dari air tanah (akuifer). Berikut merupakan peta jaringan irigasi Desa Gempol yang dapat dilihat pada Gambar 9. 


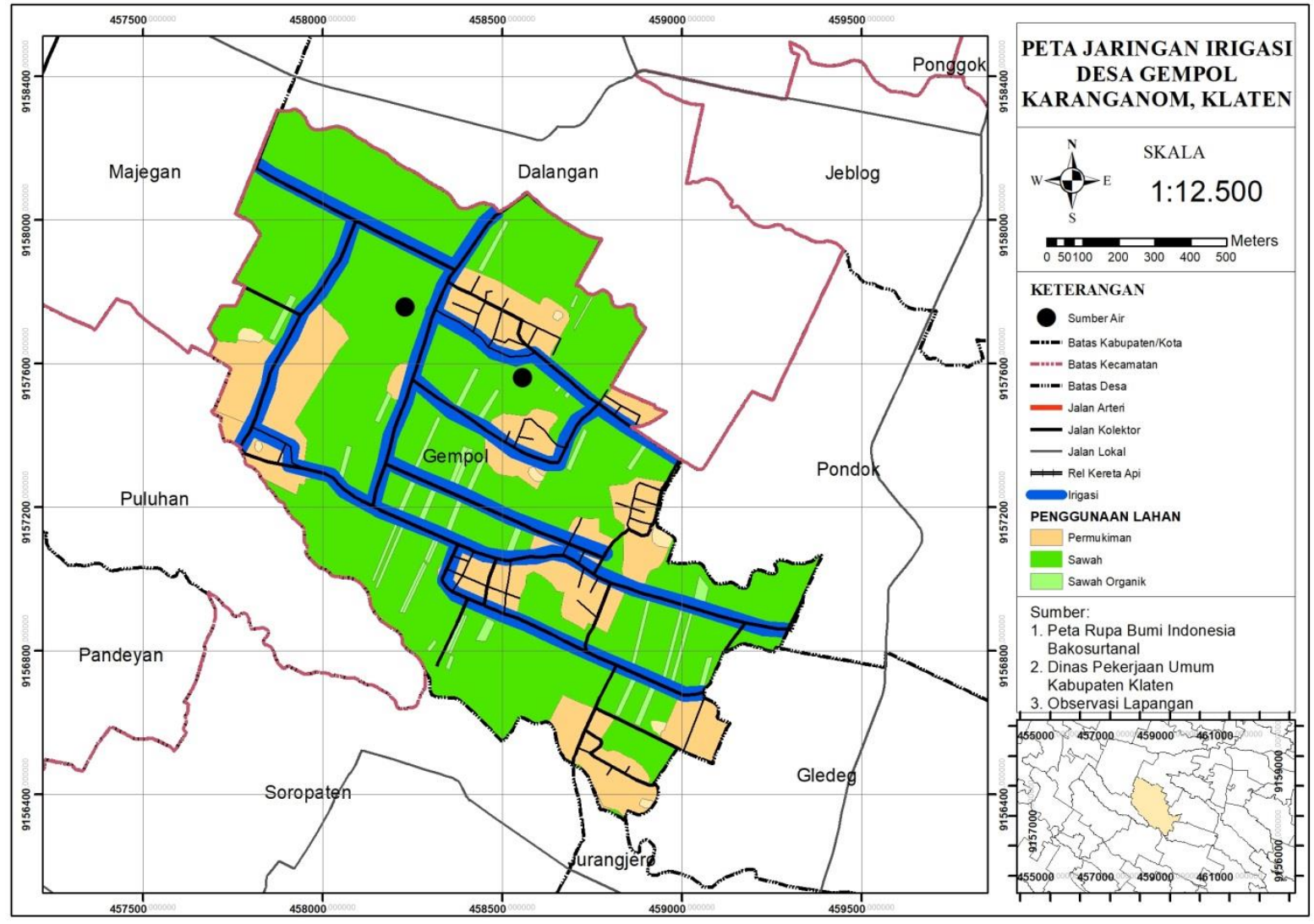

Gambar 9. Peta jaringan irigasi Desa Gempol.

Tabel 9. Skoring jaringan irigasi Desa Gempol.

\begin{tabular}{l} 
Kondisi Eksisting \\
\hline Pada Zona A, B, C dan D memperoleh air irigasi yang disaluran melalui saluran irigasi. Pada zona \\
tersebut petak sawah organik lebih berdekatan dengan saluran irigasi dibandingkan petak \\
sawah organik sehingga air irigasi yang diperoleh petak sawah organik memiliki bahan \\
pencemar yang tinggi karena air terlebih dahulu melalui petak sawah anorganik. Pada zona \\
tersebut pencemaran air tersebut dapat dikurangi dengan menggunakan kolam filter yang \\
dilengkapi dengan tanaman enceng gondok untuk menyerap bahan pencemar, seperti pupuk \\
kimia yang digunakan oleh pertanian anorganik.
\end{tabular}

\begin{tabular}{cc} 
Zona & Skor \\
\hline A & 1 \\
B & \\
C & \\
D &
\end{tabular}

Pada Zona E, F dan I petak sawah organik memperoleh air dari saluran irigasi. Pada zona tersebut letak petak sawah organik lebih berdekatan dengan saluran irigasi dibandingkan petak sawah anorganik sehingga air yang diperoleh memiliki sedikit kandungan pencemar karena tidak melalui sawah anorganik. Pada zona tersebut petak sawah organik dilengkapi dengan kolam filter guna mengurangi bahan pencemar air dari saluran irigasi.

Pada Zona G petak sawah organik memperoleh air irigasi langsung dari sumber air tanah tanpa disalurkan melalui pipa maupun saluran irigasi sehingga air yang diperoleh memiliki kualitas yang baik untuk pertanian organik. Selain itu, pada zona tersebut petak sawah organik dilengkapi dengan kolam filter untuk mengurangi bahan pencemar dalam air irigasi. 


\begin{tabular}{lcc}
\hline \multicolumn{1}{c}{ Kondisi Eksisting } & Zona & Skor \\
\hline $\begin{array}{l}\text { Pada Zona H seluruh petak sawah memperoleh air irigasi langsung dari sumber air tanah tanpa } \\
\text { disalurkan melalui saluran irigasi namun, pada zona ini tidak terdapat petak pertanian organik }\end{array}$ & 3 \\
Pada Zona K, petak sawah organik memperoleh air irigasi bersumber dari Pamsimas yang & $\mathrm{K}$ & 2 \\
kemudian disalurkan melalui pipa irigasi sehingga air tidak mengalami kontaminasi dari & \\
$\begin{array}{l}\text { pertanian anorganik. Pada petak sawah organik zona ini dilengkapi dengan kolam filter. } \\
\text { Pada Zona J, tidak terdapat pertanian organik dan pengairan. Zona tersebut sulit dilakukan }\end{array}$ & $\mathrm{J}$ & 1 \\
karena letaknya lebih tinggi dibandingkan zona lain. &
\end{tabular}

\subsection{Analisis skoring kesesuaian lahan terhadap pertanian organik}

Berdasarkan hasil identifikasi terhadap satuan kemampuan lahan di Desa Gempol dapat diperoleh hasil kemampuan lahan dengan mengacu pada Permen PU No. 20 Tahun 2007 bobot setiap satuan kemampuan lahan dapat diketahui pada Tabel 10 sebagai berikut.

Tabel 10. Pembobotan skor satuan kemampuan lahan [4].

\begin{tabular}{lc}
\hline \multicolumn{1}{c}{ Satuan Kemampuan Lahan } & Bobot \\
\hline SKL Morfologi & 5 \\
SKL Kemudahan & 1 \\
SKL Kelerengan & 5 \\
SKL Ketersediaan Air & 5 \\
SKL Erosi & 3 \\
SKL Drainase & 5 \\
SKL Bencana Alam & 5 \\
\hline
\end{tabular}

Setiap skor satuan kemampuan lahan dikalikan dengan bobot di atas kemudian dilakukan penjumlahan terhadap seluruh skor setiap satuan kemampuan lahan sehingga diperoleh skor sebagai berikut (lihat Tabel 11).

Tabel 11. Analisis skoring kemampuan lahan [4].

\begin{tabular}{|c|c|c|c|c|c|c|c|c|c|c|c|c|}
\hline \multirow{2}{*}{$\begin{array}{c}\text { Satuan } \\
\text { Kemampuan Lahan }\end{array}$} & \multirow{2}{*}{ Bobot } & \multicolumn{11}{|c|}{ Bobot SKL Zona } \\
\hline & & A & B & $\mathbf{C}$ & D & $\mathbf{E}$ & $\mathbf{F}$ & G & $\mathbf{H}$ & $\mathbf{I}$ & J & K \\
\hline SKL Morfologi & 5 & 20 & 20 & 20 & 20 & 20 & 20 & 20 & 20 & 20 & 20 & 20 \\
\hline $\begin{array}{l}\text { SKL Kemudahan } \\
\text { dikerjakan }\end{array}$ & 1 & 4 & 4 & 4 & 4 & 4 & 4 & 4 & 4 & 4 & 4 & 4 \\
\hline Kestabilan & 5 & 20 & 20 & 20 & 20 & 20 & 20 & 20 & 20 & 20 & 20 & 20 \\
\hline SKL Ketersediaan Air & 5 & 20 & 20 & 20 & 20 & 20 & 20 & 20 & 20 & 20 & 15 & 20 \\
\hline SKL Terhadap Erosi & 3 & 15 & 15 & 15 & 15 & 15 & 15 & 15 & 15 & 15 & 15 & 15 \\
\hline SKL Drainase & 5 & 15 & 15 & 15 & 15 & 15 & 10 & 10 & 10 & 10 & 10 & 10 \\
\hline SKL Bencana Alam & 5 & 15 & 15 & 15 & 15 & 15 & 20 & 20 & 20 & 20 & 20 & 20 \\
\hline Total & & 109 & 109 & 109 & 109 & 109 & 109 & 104 & 109 & 109 & 104 & 109 \\
\hline
\end{tabular}

Dari total nilai, dibuat beberapa kelas yang memperhatikan nilai minimum dan maksimum total nilai. Dari angka di atas, nilai minimum yang mungkin didapat adalah 48 , sedangkan nilai maksimum yang mungkin didapat adalah 135 . Berdasarkan perolehan nilai tersebut, dapat diperoleh interval antar kelas lahan sebanyak 10,9. Hasil tersebut diperoleh dari selisih nilai maksimum dan minimum kemudian dibagi dengan jumlah kelas, yakni 8 kelas lahan [11]. Maka, pengkelasan dari total nilai ini adalah kelas A dengan nilai 48-58,9; kelas B dengan nilai 
59-69,9; kelas $C$ dengan nilai 70-80,9; kelas D dengan nilai 81-91,9; kelas E dengan nilai 92102,9; kelas F dengan nilai 103-113,9; kelas G dengan nilai 114-124,9 dan kelas H dengan nilai $125-135,9$. Berikut merupakan tabel skoring kemampuan lahan dan jaringan irigasi yang dapat dilihat pada Tabel 12.

Tabel 12. Skoring kemampuan lahan dan jaringan irigasi.

\begin{tabular}{|c|c|c|}
\hline & $\begin{array}{c}\text { Variabel } \\
\text { Kemampuan Lahan }\end{array}$ & Variabel Jaringan Irigasi \\
\hline Sangat Sesuai (3) & $\begin{array}{l}\text { Kelas kemampuan } \\
\text { lahan I-II }\end{array}$ & $\begin{array}{l}\text { Air berasal dari air tanah, terdapat kolam filter sebagai filterisasi } \\
\text { air yang dilengkapi dengan eceng gondok }\end{array}$ \\
\hline Sesuai (2) & $\begin{array}{l}\text { Kelas kemampuan } \\
\text { lahan III-V }\end{array}$ & $\begin{array}{l}\text { Sumber air berasal dari saluran irigasi atau sungai dan terdapat } \\
\text { kolam filter namun, terdapat tumbuhan ecenggondok sebagai } \\
\text { filter }\end{array}$ \\
\hline Tidak Sesuai (1) & $\begin{array}{l}\text { Kelas kemampuan } \\
\text { lahan VI-VIII }\end{array}$ & Tidak terdapat kolam filter yang dilengkapi dengen ecenggondok \\
\hline
\end{tabular}

Berdasarkan tabel di atas, maka dapat disusun pembobotan skor untuk kesesuaian lahan pertanian organik sebagai berikut (lihat Tabel 13).

Tabel 13. Ketentuan skoring kesesuaian lahan pertanian organik.

\begin{tabular}{ccccccc}
\hline $\begin{array}{c}\text { Kesesuaian } \\
\text { lahan } \\
\text { pertanian } \\
\text { organik }\end{array}$ & $\begin{array}{c}\text { Skor } \\
\text { Maksimum }\end{array}$ & $\begin{array}{c}\text { Skor } \\
\text { Minimum }\end{array}$ & Interval & \multicolumn{3}{c}{ Keterangan } \\
\cline { 2 - 6 } \cline { 5 - 7 } & 6 & 2 & 1,3 & $4,8-6$ & $3,4-4,7$ & $2-3,3$ \\
\hline
\end{tabular}

Dari tabel di atas, kemudian dilakukan skoring pada setiap zona di Desa Gempol dan diperoleh hasil sebagai berikut (lihat Tabel 14).

Tabel 14. Analisis skoring kesesuaian lahan pertanian organik Desa Gempol.

\begin{tabular}{cccccc}
\hline & $\begin{array}{c}\text { Pembagian } \\
\text { Zona }\end{array}$ & $\begin{array}{c}\text { Skor Variabel } \\
\text { Kemampuan } \\
\text { Lahan }\end{array}$ & $\begin{array}{c}\text { Skor Variabel } \\
\text { Jaringan Irigasi }\end{array}$ & $\begin{array}{c}\text { Skor Kesesuaian } \\
\text { Lahan Pertanian } \\
\text { Organik }\end{array}$ & Keterangan \\
\cline { 2 - 6 } Kesesuaian & Zona A & 3 & 1 & 4 & Sesuai \\
lahan terhadap & Zona B & 3 & 1 & 4 & Sesuai \\
pertanian & Zona D & 3 & 1 & 4 & Sesuai \\
organik & Zona E & 3 & 1 & 4 & Sesuai \\
& Zona F & 3 & 2 & 5 & Sangat Sesuai \\
& Zona G & 3 & 3 & 5 & Sangat Sesuai \\
& Zona H & 3 & 3 & 6 & Sangat Sesuai \\
& Zona I & 3 & 2 & 5 & Sangat Sesuai \\
& Zona J & 3 & 1 & 4 & Sangat Sesuai \\
& Zona K & 3 & 2 & 5 & Sesuai \\
& & & & & Sangat Sesuai \\
\hline
\end{tabular}

Kesesuaian lahan pertanian sawah organik di Desa Gempol dilakukan dengan mencocokan kondisi eksisting Ritung et al [12], kesesuaian lahan dilakukan dengan menggunakan metode pencocokan antara persyaratan tumbuh tanaman sesuai kelas kesesuaian lahan dengan karakteristik lahan pada masing-masing unit lahan. Sedangkan menurut Ritung [3], kesesuaian 
lahan adalah tingkat kecocokan sebidang lahan untuk penggunaan tertentu yang dapat dinilai dari kondisi saat ini atau setelah dilakukan perbaikan dan tingkat kecocokan suatu bidang lahan untuk penggunaan tanaman semusim maupun tanaman tahunan [13]. Berdasarkan teori-teori tersebut, maka dapat diketahui analisis kesesuaian lahan yang dilakukan sesuai dengan teori-teori tersebut. Kesesuaian lahan pertanian organik ditinjau dari jaringan irigasi pertanian [14,15]. Berdasarkan teori-teori tersebut, diketahui bahwa untuk meninjau kesesuaian lahan terhadap pertanian organik ditinjau dari kemampuan lahan dan jaringan irigasi untuk pertanian organik.

Menurut Permentan No. 64 Tahun 2013, kesesuaian lahan pertanian sawah organik harus memiliki lahan yang terbebas dari bahan kimia [16]. Lahan pertanian sawah organik harus memiliki jaringan irigasi yang memiliki filter agar air yang masuk ke dalam petak sawah organik tidak tercemar bahan-bahan kimia [14]. Pendataan kesesuaian lahan untuk pertanian organik, meliputi pembatas antara lahan, ketinggian, curah hujan, sumber air, dan saluran irigasi. Kesesuaian lahan pertanian organik ditinjau dari kemampuan lahan. Berdasarkan teori tersebut, maka dapat diketahui bahwa kesesuaian lahan ditinjau dari satuan kemampuan lahan dan jaringan irigasi. Dari hasil analisis tersebut, dapat diketahui bahwa seluruh zona sesuai untuk petanian organik ditinjau dari kemampuan lahan. Hal ini dikarenakan kelas lahan dari setiap zona di Desa Gempol masuk ke dalam kelas kemampuan lahan III dimana kelas kemapuan lahan III sesuai untuk lahan pertanian [17]. Sedangkan ditinjau dari jaringan irigasi, terdapat lima zona yang tidak sesuai untuk jaringan irigasi pertanian organic, yaitu Zona $A$, Zona B, Zona C, Zona D dan Zona J. Selanjutnya terdapat empat zona yang sesuai untuk jaringan irigasi pertanian sawah organic, yaitu Zona $\mathrm{E}$, Zona $\mathrm{F}$, Zona I dan Zona K dan terdapat dua zona yang sangat sesuai untuk jaringan irigasi pertanian sawah organic. Sedangkan zona yang sesuai untuk jaringan irigasi pertanian organic, yaitu Zona $\mathrm{G}$ dan Zona $\mathrm{H}$. Jaringan irigasi yang sesuai untuk pertanian organik adalah jaringan irigasi yang terbebas dari penggunaan bahan kimia serta dilengkapi sarana irigasi berupa kolam filter yang dilengkapi dengan tanaman enceng gondok.

\section{Kesimpulan}

Berdasarkan hasil analisis dan pembahasan yang telah dilakukan, maka dapat ditarik kesimpulan, yakni seluruh lahan pertanian sawah organik di Desa Gempol sudah mengalami masa konversi selama 2 tahun, dimana hal tersebut merupakan syarat minimal untuk penerapan pertanian organik. Selain itu, apabila ditinjau dari kemampuan lahan, meliputi SKL morfologi, SKL kemudahan dikerjakan, SKL ketersedian air, SKL kestabilan lereng, SKL terhadap erosi, SKL drainase, dan SKL bencana alam, lahan di Desa Gempol sudah sesuai untuk diterapkan pertanian organik karena memiliki kelas lahan III dimana kelas lahan tersebut sesuai dengan peruntukan untuk lahan persawahan. Namun, ditinjau dari jaringan irigasi diketahui bahwa kesesuaian lahan di Desa Gempol memiliki lima zona yang tidak sesuai untuk diterapkan pertanian organik. Seluruh petak sawah pertanian organik di Desa Gempol dilengkapi sarana irigasi berupa kolam filter yang dilengkapi tanaman enceng gondok. Namun, beberapa lahan sawah memiliki jaringan irigasi yang tidak sesuai karena tata letak dari jaringan irigasi tersebut. Hal tersebut dikarenakan letak jaringan irigasi yang terlalu jauh 
dengan petak sawah organik dan air yang disalurkan mengandung bahan kimia karena air tersebut melalui petak sawah anorganik terlebih dahulu. Berdasarkan hal-hal tersebut, diketahui bahwa lahan di Desa Gempol sudah sesuai untuk pertanian organik. Selain itu, karena adanya lembaga tani dan standar khusus pertanian organik di Desa Gempol membuat desa tersebut menjadi percontohan untuk implementasi pertanian organik.

\section{Ucapan Terima Kasih}

Terima kasih kepada Allah SWT karena segala nikmat yang telah diberikan sehingga penelitian ini dapat terselesaikan. Penulis juga berterima kasih kepada teman-teman dan bimbingan serta partisipasi dari segala pihak yang terlibat dalam penelitian ini.

\section{Referensi}

[1] Badan Pusat Statistik. Klaten dalam Angka 20162016.

[2] Pemerintah Kab. Klaten. Peraturan Daerah Kabupaten Klaten No. 11 Tahun 2011 tentang Rencana Tata Ruang Wilayah Kabupaten Klaten 2011-2031 2011.

[3] Ritung S, Wahyunto, Agus F, Hidayat H. Panduan Evaluasi Kesesuaian Lahan. Balai Penelit Tanah Dan World Agrofor Cent 2007:48.

[4] Republik Indonesia. Peraturan Menteri Pekerjaan Umum No. 20 Tahun 2007 tentang Pedoman Teknis Analisis Aspek Fisik dan Lingkungan, Ekonomi, serta Sosial Budaya dalam Penyusunan Rencana Tata Ruang 2007.

[5] Republik Indonesia. Peraturan Pemerintah No. 20 Tahun 2006 tentang Irigasi 2006.

[6] Daldjoeni N. Geografi Kota dan Desa. Bandung: Alumni Damsar 1987; 1987.

[7] Bintarto R. Interaksi Desa Kota dan Permasalahannya. Jakarta: Ghalia Indonesia; 1983.

[8] Badan Standarisasi Nasional. SNI No 6729 Tahun 2016 tentang Sistem Pertanian Organik 2016.

[9] Gapoktan Dewi Ratih. Standar Operasional Pertanian Organik 2012.

[10] Sopian AY. Kajian Pengelolaan Aset Daerah Irigasi Cimanuk UPTD SDAP Bayongbong Dinas Sumber Daya Air dan Pertambangan Kabupaten Garut. J Irig 2013;11:1-12.

[11] Republik Indonesia. Peraturan Menteri Lingkungan Hidup No.17 Tahun 2009 tentang Pedoman Penentuan Daya Dukung Lingkungan Hidup dalam Penataan Ruag Wilayah 2009.

[12] Ritung S, Nugroho K, Mulyani A, Suryani E. Petunjuk Teknis Evaluasi Lahan untuk Komoditas Pertanian. 2011.

[13] Kementerian Pertanian. Peraturan Menteri Pertanian Nomor 79/Permentan/OT.140/8/2013 Tentang Pedoman Kesesuaian Lahan Pada Komoditas Tanaman Pangan. 2013.

[14] Jaringan Kerja Pertanian Organik. Standar Pertanian Organik Indonesia 2005.

[15] Departemen Pertanian. Panduan Penyusunan Cara Budi Daya yang Baik (Good Agriculture Practices / Gap) Pertanian Organik. Jakarta: 2007.

[16] Republik Indonesia. Peraturan Menteri Pertanian No. 64 Tahun 2013 tentang Sistem Pertanian Organik 2013.

[17] Arsyad S. Konservasi Tanah dan Air. Bogor: IPB Press; 2006. 